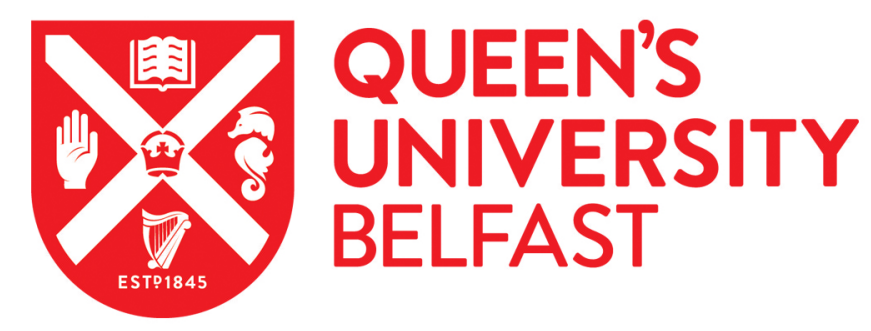

\title{
Not all social cleavages are the same: On the relationship between religious diversity and party system fragmentation
}

Raymond, C. D. (2016). Not all social cleavages are the same: On the relationship between religious diversity and party system fragmentation. Politics and Religion, 9(2), 364-388.

https://doi.org/10.1017/S1755048316000250

Published in:

Politics and Religion

Document Version:

Peer reviewed version

Queen's University Belfast - Research Portal:

Link to publication record in Queen's University Belfast Research Portal

Publisher rights

〔 2016 Religion and Politics Section of the American Political Science Association.

\section{General rights}

Copyright for the publications made accessible via the Queen's University Belfast Research Portal is retained by the author(s) and / or other copyright owners and it is a condition of accessing these publications that users recognise and abide by the legal requirements associated with these rights.

Take down policy

The Research Portal is Queen's institutional repository that provides access to Queen's research output. Every effort has been made to ensure that content in the Research Portal does not infringe any person's rights, or applicable UK laws. If you discover content in the Research Portal that you believe breaches copyright or violates any law, please contact openaccess@qub.ac.uk. 


\title{
Not all social cleavages are the same: On the relationship between religious diversity and party system fragmentation
}

\author{
Christopher D. Raymond \\ Lecturer in Politics \\ Queen's University Belfast \\ +44 (0)289097 3652 \\ C.Raymond@qub.ac.uk
}

\section{Key Words}

Religious diversity; social cleavages; party system fragmentation

\begin{abstract}
Most studies examining the relationship between social cleavages and party system fragmentation maintain that higher levels of social diversity lead to greater party system fragmentation. However, most aggregate-level studies focus on one type of social cleavage: ethnic diversity. In order to develop a better understanding of how different cleavages impact electoral competition, this paper considers another type of social cleavage: religious diversity. Contrary to previous literature, higher levels of religious diversity provide incentives for cross-religious cooperation, which in turn reduces party system fragmentation. Using a crossnational data set of elections from 1946-2011, the results show that, in contrast to most studies examining the effects of social cleavage diversity on the number of parties, higher religious diversity is associated with lower levels of party system fragmentation.
\end{abstract}

\section{Notes}

A previous version of this manuscript was presented at the 2015 Political Studies Association annual conference. The author would also like to thank the editors of Politics \& Religion and the two anonymous reviewers for their helpful comments on an earlier draft. 
Based on the seminal work by Duverger (1963; see also Cox 1997), the standard explanation of the number of parties cross-nationally holds that social cleavages drive party system fragmentation, while electoral institutions limit the number of parties in more restrictive systems (e.g. single-member district plurality systems) and allow for greater party system fragmentation in more permissive systems (e.g. proportional representation). In line with seminal research in the social cleavage tradition (Lipset and Rokkan 1967; Rokkan 1970), this model assumes that—conditional on electoral system permissiveness—diversity produces more parties. This model has been applied successively to a wide range of countries at both the national (e.g. Amorim Neto and Cox 1997; Clark and Golder 2006; Coppedge 1997; Ordeshook and Shvetsova 1994) and district (e.g. Geys 2006; Singer and Stephenson 2009) levels.

Owing to measurement difficulties that arise when operationalizing social cleavages cross-nationally, most studies focus on only one type of cleavage diversity that is (relatively) easy to operationalize: ethnic diversity. The use of ethnic diversity as a measure of total cleavage diversity has several obvious shortcomings. The most obvious is that ethnicity is but one aspect of cleavage diversity. Moreover, previous research has shown that the measure of cleavage diversity examined affects the conclusions we draw about the relationship between social cleavages and party system fragmentation (Stoll 2008). It is possible the impact of some cleavages on party system fragmentation differs from the impact of other cleavages.

This paper begins to address this lacuna in the literature by exploring the impact of religious diversity on the number of parties cross-nationally. Although most research assumes the relationship between religious diversity and party system fragmentation is positive, there is reason to believe that this relationship may actually be negative. Due to resource constraints on religious leaders resulting from competition in the religious 
marketplace, religious leaders in religiously diverse countries will seek to preserve scarce resources and enhance their influence on policy by cooperating with other cleavage groups to support parties representing shared interests. Such cooperation ultimately reduces the fragmentation of the party system. Incorporating the effects of religious diversity into the now-standard Duvergerian model used by previous studies to explain party system fragmentation and testing it using a large cross-national data set of elections from countries around the world, I find that religious diversity is associated with lower levels of party system fragmentation in restrictive electoral systems, producing increases in fragmentation only in the most permissive systems.

In the next section, I explore the relationship between religious diversity and party system fragmentation in greater detail. Following that, I outline the research design employed to test the argument before moving to a discussion of the results. A final section concludes with thoughts for future research.

\section{The Relationship between Religious Diversity and Party System Fragmentation}

In their landmark study, Lipset and Rokkan (1967; see also Rokkan 1970) argued that modern party systems have their roots in the centuries-old conflicts that continue to structure societies in the present. In addition to the two types of cleavages arising from the industrial revolution - the urban-rural and class cleavages_-Lipset and Rokkan identified two types of religious cleavages arising from the national revolution. One was a confessional cleavage pitting minority religious denominations in the periphery against the centralizing forces of established churches (as part of the larger cultural elite), while the other was a cleavage between the established churches and the developing nation-state, which sought to wrest control from religious authorities in order to establish its secular authority. The resulting party contestation along religious lines shaped the development of competitive party systems to a considerable extent in many countries (Caramani 2004; Ertman 2009). 
Following in this tradition, studies seeking to explain the number of parties crossnationally have assumed that greater cleavage diversity yields more fragmented party systems. In nearly every instance, however, previous studies examining the determinants of party system fragmentation have only focused on ethnic diversity, due in part to convenience, though also due to difficulties in measuring all cleavages precisely from one context to another (Stoll 2008). With only few exceptions (e.g. Madrid 2005), these studies show that various measures of ethnic diversity tend to be associated with more fragmented party systems, conditional on the proportionality of the electoral system (Amorim Neto and Cox 1997; Clark and Golder 2006; Geys 2006; Ordeshook and Shvetsova 1994; Singer and Stephenson 2009).

Those few studies that do include measures of religious cleavages do not focus on religion per se. For instance, Powell (1982) examined the effect of Catholic minority populations on legislative party system fragmentation. Other studies find a positive relationship between social diversity and party system fragmentation (Lijphart 1999), though such effects may be non-monotonic and/or conditional on institutional factors (Potter 2014; Stoll 2013). While this sort of attention to a broad group of cleavage variables-including religion — is a welcome development, assuming all cleavage diversity produces greater party system fragmentation may not be warranted. It could be that the impact of religious diversity on the number of parties differs from the effects of other social cleavages. For instance, in examining the robustness of the relationship between various measures of social diversity and party system fragmentation, previous research finds that variables measuring religious diversity have the "wrong” sign when compared to variables such as ethnic diversity (Stoll 2008; see also Lowery et al. 2013). Until now, studies have not asked whether these findings are genuine or mere aberrations from what we expect should be a positive relationship.

There may be reason to expect a negative relationship between religious diversity and 
party system fragmentation. According to the supply-side theory of religiosity, the vitality of religious organizations and religious devotion are determined by the patterns of competition among religious actors (i.e. the supply-side of religion). In markets (i.e. countries) where religious competition is regulated—whether through state subsidy for and/or sponsorship of particular religious organizations, or by legal restrictions on certain organizations/practicesreligious organizations face little competition for survival, which leads to low levels of religious devotion and diversity. In markets where state support is absent, religious organizations must compete for adherents in order to survive. This competition leads religious organizations to work harder to attract adherents than religious groups in uncompetitive markets, which in turn leads to greater religious diversity (Berger 1963; Finke and Stark 1988; Iannaccone, Finke, and Stark 1997; Stark and Iannaccone 1994).

Whereas party system fragmentation in uncompetitive religious markets is restrained only by electoral systems and the other social cleavage structures, the competition for religious adherents characterizing competitive religious markets puts downward pressure on the number of viable parties. Unlike the institutionalized positions of religious leaders belonging to state-supported organizations that do not need to compete for adherents in order to survive, the influence of religious leaders — whether direct over policy or merely to preserve their autonomy over religious issues (Jelen and Wilcox 2002: 317-319)—in competitive markets is not guaranteed, but rather determined by their market share (number of adherents). Instead of each religious group forming its own party, competition creates incentives for religious leaders in religiously diverse markets to cooperate with those sharing similar policy concerns (including both the leaders of other religious organizations and those concerned with other cleavage-group issues) in order to increase their political influence on religious issues. Similar to other types of organizations in competitive markets (e.g. van de Ven 1976), such cooperation also preserves scarce resources that are better served in 
competition for adherents in the religious marketplace (Berger 1963; Miller 2002; Wagner 1997). As religious diversity increases, the incentives to cooperate increase as well, thereby reducing party system fragmentation.

The reduction in party system fragmentation resulting from such cooperation can take one of two forms. One is where religion becomes the dominant cleavage, as elections are turned into battles fought along confessional and/or religious-secular lines that rally support from other overlapping (as opposed to cross-cutting) cleavages; this, in turn, reinforces the primacy of religious cleavages (see Coleman 1956). The other is when religious cleavages are disarticulated and incorporated within the prevailing partisan divides. In these situations, religious leaders will seek to preserve their influence by finding ways in which confessional and/or religious-secular interests map onto existing issue dimensions (e.g. class, ethnic, etc.), and bargaining religious voters' support for parties with similar interests in exchange for influence over issues of great import to religious voters (e.g. abortion, same-sex marriage, etc.). Ultimately, the choice between these two strategies is made by elites, who articulate the cleavages that best serve their electoral and policy interests (Enyedi 2005; Przeworski and Sprague 1986; Torcal and Mainwaring 2003). Because religious issues—often distinct from “normal” issues (e.g. Smith and Tatalovich 2003; Studlar, Cagossi, and Duval 2013; Tribe 1992), owing to the levels of conviction (e.g. Ryan 2014; see also Skikta 2010) and supernatural consequences for those involved (e.g. Grzymala-Busse 2012; Stark 1999; Stark and Finke 2000)—are so fundamental to religious adherents, religious leaders will prefer the second strategy when religious issues are not the prevailing partisan divides because cooperation increases the chances that they will be able to influence policies concerning religion.

We can see several specific examples of this type of cooperation resulting from market pressures in previous literature. For instance, the Catholic Church only began to 
cooperate with and articulate the concerns of indigenous Mexicans—after years of ignoring their concerns_-when the Church began to feel the threat to their position (religious and political) created by the increasing numbers converting to Protestant denominations (Trejo 2009). Catholic clergy also cooperated with opposition groups against authoritarian leaders in Latin American countries where they faced pressure from growing Protestant churchesbut not where any such pressure was absent (Gill 1994). Elsewhere, religious elites whose positions are threatened by increasingly secular publics have subsumed confessional cleavages under religious-secular cleavages, as with the formation of Christian Democratic Appeal in the Netherlands (Lucardie and ten Napel 1994), and religious-secular realignments in the United States (Layman 2001) and Chile (Raymond and Feltch 2014). One could even argue that the survival of Christian Democratic parties in an age of secularization has been achieved by compromise between religious and class/other cleavage groups (Duncan 2006; Elff and Rossteutscher 2011), which has been true of their entire postwar histories (Kalyvas 1996; Kalyvas and van Kersbergen 2010). Additionally, religious leaders in diverse societies competing along a dominant versus minority religious cleavage often seek to incorporate overlapping ethnic and/or class issues into their struggles-e.g. establishment Protestants of British descent versus disadvantaged Catholic minority ethnic groups in Australia (Bean 1999) and Canada (Blais 2005).

While religious elites in diverse societies do have the option to support parties contesting elections separately from parties representing other cleavages, this strategy will result in wasted resources and reduced influence over religious issues in all but the most permissive electoral systems. If the electoral system is not sufficiently permissive to weaken oppositional forces by promoting a high degree of party system fragmentation among nonreligious (class, ethnic, etc.) parties, then it will be in the best interests of religious party leaders to cooperate with leaders representing other cleavage issues in order to preserve 
resources and maximize policy influence. As a result, we should only see a positive relationship between religious diversity and party system fragmentation in the most permissive electoral systems: it is only in these systems where party system fragmentation will be sufficient enough that religious-secular and/or confessional parties will have the ability to compete with non-religious parties and/or one another for influence over policies regarding religious issues.

The products of these religious market forces can be seen more clearly by examining the case of New Zealand in comparative perspective. Although relatively homogeneous in terms of ethnic diversity, ${ }^{1}$ New Zealand is religiously diverse, divided primarily among Protestant, Catholic, and secular lines, though with small-but-significant Hindu, Buddhist, and Muslim minorities as well (Vaccarino, Kavan, and Gendall 2011). Despite its religious diversity, and despite its use of a mixed-member proportional electoral system since 1996, religious-based parties have not found much success in New Zealand: though many Christian Democratic parties have contested elections in New Zealand, few have won more than a handful of seats (Barker and McLeay 2000), with no such party winning any representation since the 2008 elections. Instead, religious issues - to the extent that they feature in New Zealand politics - tend to map onto the class cleavage, with Protestant voters supporting the right-of-center National Party and Catholic and secular voters supporting the left-of-center Labour Party (e.g. Bean 1988; Medeiros and Noël 2013). Interpreted through the framework presented above, religious elites (and voters) have operated primarily within the traditional bounds of the two-party National-Labour party system because religious parties would not and have not featured very prominently in New Zealand party politics. If religious leaders were to compete for power primarily through an explicitly religious party, religious issues would not receive much expression. As a result, party system fragmentation in New Zealand is much lower than one would expect given its level of religious diversity (assuming the 
relationship between religious diversity and party system fragmentation was positive): in the six elections between 1996 and 2011 (all held under a mixed-member proportional electoral system), the effective number of electoral parties averaged just over 3.5.

In comparison with another country of roughly similar social and institutional structures, Lithuania, the impact of religious diversity on New Zealand’s party system becomes more apparent. Information regarding both countries' electoral systems, as well as the effective numbers of ethnic groups, religious groups, and parties' vote shares appears in Table 1. Both countries award nearly equal parliamentary seat shares in the upper tier of their mixed-member proportional electoral systems. As seen in Table 1, both countries areethnically speaking—relatively homogeneous. Where the two countries differ-and differ quite significantly_-is in terms of their respective levels of religious diversity. Unlike New Zealand, Lithuania is less religiously diverse, with Catholics comprising nearly 80 percent of the population; the next largest group is the non-religious, at just over six percent (Statistics Lithuania 2013). In this context, parties from several major party families_including Christian Democratic parties—have competed successfully for votes (Bakke 2010; Ramonaité 2006). As a result, party system fragmentation in Lithuania is far greater than in New Zealand: the average effective number of parties in elections since the end of Communism exceeds seven, as seen in Table 1. Although not demonstrative, the clear difference in religious diversity between the two countries does at least suggest the possibility that religious diversity may be negatively associated with party system fragmentation.

[Table 1 about here]

When compared with the Netherlands — which is a country of relatively equal ethnic and religious diversity to that seen in New Zealand—it is the Netherlands' much more fragmented party system that requires explanation (instead of the other way around). As seen in Table 1, the average effective number of parties in the Netherlands from 1998-2010 
(roughly corresponding to the same period examined in New Zealand) was 5.8. Here, the disparity in party system fragmentation between the two countries may be due to a key difference between the two countries’ proportional electoral systems: district magnitude. While New Zealand's mixed-member proportional electoral system elects half of the available seats in its proportional tier to compensate for disproportional seat shares awarded in the lower tier, the Netherlands elects all 150 members of the House of Representatives in a single nation-wide constituency using proportional representation. Because of the interaction posited between district magnitude and social cleavages in Duvergerian models of party system fragmentation (e.g. Amorim Neto and Cox 1997; Clark and Golder 2006; Geys 2006; Ordeshook and Shvetsova 1994; Singer and Stephenson 2009), it is possible that the number of parties in the Netherlands is greater than in New Zealand only because the Dutch electoral system is sufficiently permissive for religious diversity to sustain the higher levels of fragmentation seen in Table 1. Interestingly, however, party system fragmentation is lower in the Netherlands than in Lithuania despite the former's use of a highly proportional electoral system, suggesting the greater religious diversity in the Netherlands may explain the lower level of fragmentation there.

\section{Research Design}

The discussion above suggests that, contrary to previous expectations, the relationship between religious diversity and party system fragmentation may be negative. In order to test this possibility, I examine a Duvergerian model of party system fragmentation incorporating the effects of social cleavages, electoral institutions, and the interaction of these two types of variables. In order to contribute to the already well-established literature on this subject, I incorporate religious diversity into a widely used model that is consistent with Duverger's argument (see e.g. Amorim Neto and Cox 1997; Clark and Golder 2006; Ordeshook and Shvetsova 1994). This model takes the following form: 
ENEP $=\beta_{0}+\beta_{1} \log ($ Ethnic Diversity $)+\beta_{2} \log M+\beta_{3} \log ($ Ethnic Diversity $) \times \log M+$ $\beta_{4}$ Upper Tier $+\beta_{5} \log ($ Ethnic Diversity $) \times$ Upper Tier $+\beta_{6}$ Proximity $+\beta_{7}$ ENPRES + $\beta_{8}$ Proximity $\times$ ENPRES $+\epsilon$

The dependent variable, ENEP, is the effective number of parties in elections for the legislature (the lower house in the case of bicameral legislatures). ${ }^{2}$ ENEP is measured as $1 / \sum_{i=1}^{n} p_{i}^{2}$, where $\mathrm{n}$ is the number of parties and $\mathrm{p}_{\mathrm{i}}$ is the proportion of votes won by the $\mathrm{i}^{\text {th }}$ party. ${ }^{3}$ Data for this variable are taken from the "Democratic Systems Around the World, 1946-2011” data set collected by Bormann and Golder (2013). Their data set includes all legislative elections between 1946 and 2011 from countries meeting minimal democratic criteria (namely, the criteria set out by Alvarez et al. 1996). ${ }^{4}$ Because this data set includes a vastly larger number of countries and elections than previous research looking at the relationship between religious diversity and party system fragmentation, the analysis below provides a more generalizable test of the impact of religious diversity.

Ethnic Diversity is measured as the (logged) effective number of ethnic groups. Similar to ENEP, the effective number of ethnic groups is measured as $1 / \sum_{i=1}^{n} e_{i}^{2}$, where $\mathrm{e}_{\mathrm{i}}$ is the proportion of the population belonging to the $\mathrm{i}^{\text {th }}$ ethnic group. I use this measure of ethnic diversity in order to follow the practice of Clark and Golder (2006), who calculate the effective number of ethnic groups using data from Fearon (2003). ${ }^{5}$ Because some research has documented nonlinearity in the relationship between ethnic diversity and party system fragmentation (Raymond 2015), I use the logged effective number of ethnic groups.

This model includes two variables to capture the effects of electoral systems on party system fragmentation — LogM and Upper Tier — both of which are interacted with Ethnic Diversity. Following the longstanding observation that party system fragmentation tends to be greater in districts with larger district magnitudes (Taagepera and Shugart 1989), this model includes a variable measuring the (logged) mean district magnitude ( $\log M)$. Because Duverger's (1963) hypothesis predicts that diverse social structures will produce multiparty 
systems only if electoral systems are sufficiently permissive (and vice versa), an interaction between Ethnic Diversity and LogM is included. To account for the fact that seats in some countries' legislatures are awarded in multiple tiers (e.g. as a means to address distortion in the votes-seats ratio produced by the use of single-member districts, as in New Zealand), this model includes a variable measuring the percentage of seats in the lower house awarded in upper tiers (Upper Tier). Recognizing the effect of this variable may be conditioned by Ethnic Diversity in ways similar to LogM, I include an interaction between Upper Tier and Ethnic Diversity.

One concern with estimating the effects of electoral systems on party system fragmentation is the possibility the choice of electoral systems is endogenous (e.g. Boix 1999; Colomer 2005; Leeman and Mares 2014). The most relevant concern here is that electoral systems are determined by the social structure — that countries employing more proportional electoral systems do so because their social structures are more diverse (Lundell 2010: 32-40; Rokkan 1970). However, when looking at the differences in ethnic and religious diversity between countries with single-member districts and those with district magnitudes greater than one and/or upper tiers (using the sample of countries used in the regression analyses), it turns out that—contrary to most expectations (however, see Horowitz 1985) — the most ethnically and religiously diverse countries are those with single-tier, singlemember district electoral systems (significantly so at the $\mathrm{p}<0.001$ level). Although the data do not allow us to rule out the possibility that the choice of electoral system is determined by the fragmentation of the party system, if electoral system variables are endogenous, this would mean that any shared variance with religious diversity is attributed by the model to electoral system effects instead of religious diversity. This biases religious diversity coefficients in favor of the null hypothesis — suggesting that any negative effect of religious diversity will be under-estimated (i.e. erring on the side of caution). 
To capture the impact of presidential systems on legislative party systems, this model includes Proximity (the time between the legislative election and the most recent presidential election), ENPRES (the effective number of presidential candidates in the most recent election), and an interaction between the two. Following the practice established by (Amorim Neto and Cox 1997), Proximity is measured as the time elapsed between presidential and legislative elections using a continuous scale ranging from zero (for midterm elections_-as well as non-presidential systems) to one (legislative and presidential elections are held concurrently). Data for this variable are taken in part from the "Democratic Elections Around the World, 1946-2000” data set collected by Golder (2005), with missing data collected by the author. ENPRES is calculated as $1 / \sum_{i=1}^{n} c_{i}^{2}$, where $\mathrm{c}_{\mathrm{i}}$ is the proportion of votes won by the $\mathrm{i}^{\text {th }}$ candidate. Data for this variable are taken from Bormann and Golder (2013). The logic behind these variables is that the fragmentation of the presidential party system will increase legislative party system fragmentation, though primarily when presidential and legislative elections are held concurrently.

To determine the relationship between religious diversity and party system fragmentation, I simply incorporate a variable measuring the effective number of religious groups into the model above. To account for possible nonlinearity in the relationship between religious diversity and party system fragmentation similar to that observed with ethnic diversity, I use the logged functional form of religious diversity. Additionally, because the received wisdom derived from Duverger suggests that the effects of religious diversity may be conditioned by properties of the electoral system in ways similar to other cleavage variables like ethnic diversity, I include interactions between religious diversity and both LogM and Upper Tier. The revised model examined in the empirical analysis below takes the following form:

$$
\text { ENEP }=\beta_{0}+\beta_{1} \log (\text { Religious Diversity })+\beta_{2} \log (\text { Ethnic Diversity })+\beta_{3} \log M+
$$


$\beta_{4} \log \left(\right.$ Religious Diversity) $\times \log M+\beta_{5} \log ($ Ethnic Diversity $) \times \log M+\beta_{6} U$ Uper

Tier $+\beta_{7} \log ($ Religious Diversity $) \times$ Upper Tier $+\beta_{8} \log ($ Ethnic Diversity $) \times$ Upper

Tier $+\beta_{9}$ Proximity $+\beta_{10}$ ENPRES $+\beta_{11}$ Proximity $\times$ ENPRES $+\epsilon$

Because previous research has shown that the relationship between social diversity and the number of parties may depend on the measure used (Stoll 2008), I estimate three models, each using one of three different measures of religious diversity to determine the robustness of the findings using any one measure. The first measure of religious diversity is taken from Fearon and Laitin (2003), who create their measure of religious diversity using data from the Central Intelligence Agency World Factbook. A second variable uses religious fractionalization data from Alesina et al. (2003). A third variable is created using data from the Pew Research Center (2014). Because the raw data taken from this study did not disaggregate the percentage of Christians into separate denominations, I supplemented this data set with other data from Pew (2011) measuring the percentage of each country belonging to Protestant, Catholic, and Orthodox traditions. ${ }^{6}$ Descriptive statistics for these and each of the other variables are presented in Table 2.

[Table 2 about here]

To estimate these models, I use ordinary least squares regression. Because the Bormann and Golder (2013) data set includes multiple elections for some countries, which may lead to under-estimated standard errors, I use country-clustered standard errors. I do so for three reasons. First, this follows the practice of Clark and Golder (2006); by following their practice, the results presented here can be compared to those produced in their earlier study. Second, while the data set used here includes multiple elections in some countries, time-series methods are generally considered inappropriate due to the irregular intervals between election periods both within and across countries. Third, the estimates presented below are even more conservative than those using panel-corrected standard errors (in which the consecutive number of elections is treated as a unit of time), as well as models using 
bootstrapped standard errors (see the results presented in Appendix 1 and 2, respectively).

\section{Results}

Parameter estimates for the three regression models are presented in Table 3. While the interpretation of interaction effects necessitates caution-requiring that we interpret the effect of one variable in the interaction conditional on the other-some preliminary conclusions can be gleaned from Table 3. When looking at the regression coefficients for each of the three religious diversity variables, which represent the relationship between religious diversity and party system fragmentation when $\log M$ equals zero (i.e. countries where district magnitude equals one), we see that the coefficients are negative and statistically significant. ${ }^{7}$ It is worth noting that the interaction between religious diversity and Upper Tier is small and statistically insignificant, which indicates that upper tiers do not have much bearing on the underlying relationship between religious diversity and party system fragmentation. This implies that, at least in single-member district systems, party system fragmentation decreases as religious diversity increases. Additionally, the coefficients for the interaction between religious diversity and LogM in each model are positive, implying that party system fragmentation increases (or at least that the negative association between religious diversity and party system fragmentation weakens) as district magnitude increases.

[Table 3 about here]

The precise estimated impact of religious diversity can be seen more clearly in Figure 1, which presents the relationships between religious diversity (using the Fearon and Laitin measure) and party system fragmentation at different levels of $\log M$ : zero (i.e. singlemember districts), two (roughly corresponding to mean district magnitudes of 7.4) and four (roughly corresponding to mean district magnitudes of 54.6). ${ }^{8}$ This allows us to examine the conditional relationships between religious diversity and party system fragmentation, which in turn allows us to determine whether the negative relationship seen in single-member 
districts holds in more permissive electoral systems.

[Figure 1 about here]

As the results presented in Figure 1 show, the negative relationship seen when looking at the coefficient associated with religious diversity is not limited solely to single-member district systems. In fact, this negative relationship holds in many proportional electoral systems as well, as evidenced by the weak negative relationship in countries with mean district magnitudes of $7.4(\log M=2)$. As represented by the predicted relationship when $\log M$ equals four, it is only as we approach higher values of $\log M$ that the relationship becomes positive and significantly different from the relatively flatter relationship seen at $\log M$ values of two. Given that relatively few countries have electoral systems this permissive ( $\log M$ values greater than 2.8 fall into the $90^{\text {th }}$ percentile of countries in this sample), this suggests that the relationship between religious diversity and party system fragmentation is negative in all but the handful of countries with highly proportional electoral systems.

In addition to the fact that the predicted relationship between religious diversity and party system fragmentation is negative in a large number of countries, the results in Figure 1 demonstrate that the estimated impact of religious diversity on party system fragmentation is quite powerful. Going from the lowest to the highest values of religious diversity in singlemember district countries (i.e. $\log M=0$ ), ENEP decreases by effectively 1.7 parties. While the discussion above shows that this relationship is tempered by the permissiveness of the electoral system, the results in Figure 1 demonstrate that not only is the relationship between religious diversity and the number of parties negative, but also that religious diversity has a significant constraining effect on the fragmentation of the party system.

These findings are not due to the choice of religious diversity measure. As can be seen in Figures 2 and 3-which present the conditional relationships between religious 
diversity and party system fragmentation when using the Alesina et al. (2003) and Pew (2014) measures of religious diversity, respectively—-the relationships presented in Figure 1 are quite robust. In both figures, the relationship between religious diversity and party system fragmentation is strongly negative in single-member district systems. This relationship nearly flattens out in Figure 2 for those countries where $\log M$ equals two. While the relationship becomes positive in Figure 3 for those countries where $\log M$ equals two, it is slightly positive at best. As in Figure 1, the relationship between religious diversity and party system fragmentation in Figures 2 and 3 is clearly positive only in those countries with highly permissive electoral systems.

[Figures 2 and 3 about here]

Thus, the results presented here provide considerable support for the notion that the relationship between religious diversity and party system fragmentation is negative in all but the most permissive electoral systems. In contrast to the overwhelming majority of the literature dealing with the impact of social cleavages on the development of party systems, the results presented in this section suggest that not all social cleavage diversity produces greater party system fragmentation. Consistent with expectations derived from the supplyside theory of religiosity, these results suggest that religious diversity leads to lower-not greater-party system fragmentation, regardless of the religious diversity measure used.

\section{Conclusion}

Most studies focusing on the development of party systems have assumed that greater cleavage diversity produces more fragmented party systems. This presumes, however, that higher levels of diversity lead to greater party system fragmentation for each type of cleavage. When testing this argument cross-nationally, however, most research has focused solely on one aspect of cleavage diversity: ethnicity. With few exceptions, other cleavages like religion have been excluded from Duvergerian models of party system fragmentation. 
Building on the work of others voicing similar concerns (e.g. Stoll 2008), this paper has shown that the neglect of other cleavages and the assumption that all cleavage diversity produces greater fragmentation merit re-examination. Consistent with expectations derived from the supply-side theory of religiosity, the relationship seen here between religious diversity and party system fragmentation cross-nationally is negative—and robustly so — in a large number of countries. While the relationship between religious diversity and party system fragmentation becomes positive in more proportional electoral systems, the fact remains that it is only in the most proportional electoral systems where greater levels of religious diversity produce more parties. This stands in sharp contrast to the expectations of the literature.

Despite the fact the relationships presented here are robust to different measures of religious diversity, this piece offers what is admittedly only a preliminary step toward a better understanding of the impact of social cleavages on the number of parties cross-nationally. Obviously, future research will need to continue to expand the focus beyond ethnic and religious cleavages. Additionally, although this paper has advanced an argument as to why we might expect to see a negative relationship between religious diversity and party system fragmentation, this should not be the last word on this matter. Even if the findings presented here are confirmed by future research, more work is needed to test whether key aspects of the argument presented here are valid, or whether other forces better explain the relationships observed here. As part of this effort, the supply-side religiosity argument presented here should be subjected to scrutiny in other ways—-for instance, testing the argument diachronically_and at different levels (e.g. at the district level rather than the national level). Additionally, more work studying how religious leaders cooperate with one another and with leaders from other cleavage groups as religious diversity increases and religious cleavages become entangled with other cleavages. Future research on this matter should examine under 
what conditions religious cleavages subsume other cleavages and under what conditions religious cleavages are subsumed in order to preserve religious leaders’ influence. 


\section{References}

Alesina, Alberto, Arnaud Devleeschauwer, William Easterly, Sergio Kurlat, and Romain Wacziarg. 2003. “Fractionalization.” Journal of Economic Growth 8 (2): 155-194. Alvarez, Mike, José Antonio Cheibub, Fernando Limongi, and Adam Przeworski. 1996. “Classifying Political Regimes.” Studies in Comparative International Development 31 (2): 3-36.

Amorim Neto, Octavio and Gary W Cox. 1997. "Electoral institutions, cleavage structures and the number of parties.” American Journal of Political Science 41 (1): 149-174.

Bakke, Elisabeth. 2010. “Central and East European party systems since 1989.” In Central and Southeast European Politics Since 1989, ed. Sabrina P. Ramet. New York: Cambridge University Press, pp. 64-90.

Barker, Fiona and Elizabeth McLeay. 2000. "How Much Change? An Analysis of the Initial Impact of Proportional Representation on the New Zealand Parliamentary Party System.” Party Politics 6 (2): 131-154.

Bean, Clive. 1988. "Class and Party in the Anglo-American Democracies: The Case of New Zealand in Perspective.” British Journal of Political Science 18 (3): 303-321.

Bean, Clive. 1999. “The Forgotten Cleavage? Religion and Politics in Australia.” Canadian Journal of Political Science 32 (3): 551-568.

Berger, Peter L. 1963. “A Market Model For the Analysis of Ecumenicity.” Social Research 30 (1): 77-93.

Blais, André. 2005. “Accounting for the Electoral Success of the Liberal Party in Canada: Presidential Address to the Canadian Political Science Association London, Ontario June 3, 2005.” Canadian Journal of Political Science 38 (4): 821-840.

Boix, Carles. 1999. "Setting the Rules of the Game: The Choice of Electoral Systems in Advanced Industrial Democracies.” American Political Science Review 93 (3): 609- 
624.

Bormann, Nils-Christian and Matt Golder. 2013. “Electoral Systems Around the World: 1946-2011.” Electoral Studies 32 (2): 360-369.

Caramani, Daniele. 2004. The Nationalization of Politics: The Formation of National Electorates and Party Systems in Western Europe. New York: Cambridge University Press.

Clark, William Robert and Matt Golder. 2006. "Rehabilitating Duverger’s theory testing the mechanical and strategic modifying effects of electoral laws.” Comparative Political Studies 39 (6): 679-708.

Coleman, James S. 1956. “Social Cleavage and Religious Conflict.” Journal of Social Issues 12 (3): 44-56.

Colomer, Josep M. 2005. “It’s Parties That Choose Electoral Systems (or, Duverger’s Laws Upside Down).” Political Studies 53 (1): 1-21.

Coppedge, Michael. 1997. “District Magnitude, Economic Performance, and Party-System Fragmentation in Five Latin American Countries.” Comparative Political Studies 30 (2): 156-185.

Cox, Gary W. 1997. Making Votes Count: Strategic Coordination in the World's Electoral Systems. New York: Cambridge University Press.

Duncan, Fraser. 2006. “A Decade of Christian Democratic Decline: The Dilemmas of the CDU, ÖVP and CDA in the 1990s.” Government and Opposition 41 (4): 469-490.

Duverger, Maurice. 1963. Political parties: Their organization and activity in the modern state. New York: John Wiley.

Elff, Martin and Sigrid Rossteutscher. 2011. "Stability or Decline? Class, Religion and the Vote in Germany.” German Politics 20 (1): 107-127.

Enyedi, Zsolt. 2005. “The role of agency in cleavage formation.” European Journal of 
Political Research 44 (5): 697-720.

Ertman, Thomas. 2009. "Western European party systems and the religious cleavage.” In Kees Van Kersbergen and Philip Manow (eds.), Religion, class coalitions, and welfare states. New York: Cambridge University Press, pp. 39-55.

Fearon, James D. 2003. “Ethnic and Cultural Diversity by Country.” Journal of Economic Growth 8 (2): 195-222.

Fearon, James D. and David D. Laitin. 2003. "Ethnicity, Insurgency, and Civil War.” American Political Science Review 97 (1): 75-90.

Finke, Roger and Rodney Stark. 1988. "Religious economies and sacred canopies: Religious mobilization in American cities, 1906.” American Sociological Review 53 (1): 41-49.

Geys, Benny. 2006. “District Magnitude, Social Heterogeneity and Local Party System Fragmentation.” Party Politics 12 (2): 281-297.

Gill, Anthony J. 1994. "Rendering unto Caesar? Religious competition and Catholic political strategy in Latin America, 1962-79.” American Journal of Political Science 38 (2): 403-425.

Golder, Matt. 2005. “Democratic Electoral Systems Around the World, 1946-2000.” Electoral Studies 24 (1): 103-121.

Grzymala-Busse, Anna. 2012. “Why Comparative Politics Should Take Religion (More) Seriously.” Annual Review of Political Science 15: 421-442.

Horowitz, Donald L. 1985. Ethnic Groups in Conflict: Theories, Patterns, and Policies. Berkeley: University of California Press.

Iannaccone, Laurence R., Roger Finke, and Rodney Stark. 1997. “Deregulating Religion: The Economics of Church and State.” Economic Inquiry 35 (2): 350-364.

Jelen, Ted G. and Clyde Wilcox. 2002. “The Political Roles of Religion.” In Ted Gerard Jelen and Clyde Wilcox (eds.), Religion and Politics in Comparative Perspective: The 
One, the Few, and the Many. Cambridge: Cambridge University Press, pp. 314-329.

Kalyvas, Stathis N. 1996. The Rise of Christian Democracy in Europe. Ithaca: Cornell University Press.

Kalyvas, Stathis N. and Kees van Kersbergen. 2010. “Christian Democracy.” Annual Review of Political Science 13: 183-209.

Layman, Geoffrey C. 2001. The Great Divide: Religious and Cultural Conflict in American Party Politics. New York: Columbia University Press.

Leeman, Lucas and Isabela Mares. 2014. “The Adoption of Proportional Representation.” Journal of Politics 76 (2): 461-478.

Lijphart, Arend. 1999. Patterns of Democracy: Government Forms and Performance in Thirty-Six Countries. New Haven: Yale University Press.

Lipset, Seymour Martin and Stein Rokkan, eds. 1967. Party systems and voter alignments: Cross-national perspectives. New York: Free Press.

Lowery, David, Arjen van Witteloostuijn, Gábor Peli, Holly Brasher, Simon Otjes, and Sergiu Gherghina. 2013. "Policy agendas and births and deaths of political parties.” Party Politics 19 (3): 381-407.

Lucardie, Paul and Hans-Martien ten-Napel. 1994. "Between confessionalism and liberalconservativism: the Christian Democratic parties of Belgium and the Netherlands.” In Christian Democracy in Europe: A Comparative Perspective, ed. David Hanley. London: Pinter, 51-70.

Lundell, Krister. 2010. The Origin of Electoral Systems in the Post-War Era. London: Routledge.

Madrid, Raúl L. 2005. “Indigenous voters and party system fragmentation in Latin America.” Electoral Studies 24 (4): 689-707.

Medeiros, Mike and Alain Noël. 2013. “The Forgotten Side of Partisanship: Negative Party 
Identification in Four Anglo-American Democracies.” Comparative Political Studies 47 (7): 1022-1046.

Miller, Kent D. 2002. “Competitive Strategies of Religious Organizations.” Strategic Management Journal 23 (5): 435-456.

Ordeshook, Peter and Olga Shvetsova. 1994. “Ethnic heterogeneity, district magnitude, and the number of parties.” American Journal of Political Science 38 (1): 100-123.

Pew Research Center. 2011. “Table: Christian Population in Numbers by Country.” Accessed on 1 August 2014 at: <http://www.pewforum.org/2011/12/19/table-christianpopulation-in-numbers-by-country/> .

Pew Research Center. 2014. “Table: Religious Diversity Index Scores by Country.” Accessed on 1 August 2014 at: <http://www.pewforum.org/2014/04/04/religious-diversityindex-scores-by-country/>.

Potter, Joshua D. 2014. “Demographic Diversity and District-Level Party Systems.” Comparative Political Studies, 47 (13): 1801-1829.

Powell, G. Bingham. 1982. Contemporary Democracies: Participation, Stability, Violence. Cambridge: Harvard University Press.

Przeworski, Adam and John Sprague. 1986. Paper Stones: A History of Electoral Socialism. Chicago: University of Chicago Press.

Ramonaité, Ainè. 2006. “The development of the Lithuanian party system: from stability to perturbation.” In Post-Communist EU Member States: Parties and Party Systems, ed. Susanne Jungerstam-Mulders. Burlington, VT: Ashgate, pp. 69-90.

Raymond, Christopher D. and Brian M. Barros Feltch. 2014. "Parties, cleavages and issue evolution: The case of the religious-secular cleavage in Chile.” Party Politics 20 (3): 429-443.

Raymond, Christopher D. 2015. “The organizational ecology of ethnic cleavages: The 
nonlinear effects of ethnic diversity on party system fragmentation.” Electoral Studies 37 (2): 109-119.

Rokkan, Stein. 1970. Citizens, Elections, Parties. New York: David McCay.

Ryan, Timothy J. 2014. “Reconsidering Moral Issues in Politics.” Journal of Politics 76 (2): 380-397.

Singer, Matthew M. and Laura B. Stephenson. 2009. “The political context and Duverger's theory: Evidence at the district level.” Electoral Studies 28 (3): 480-491.

Skikta, Linda J. 2010. “The Psychology of Moral Conviction.” Social and Personality Psychology Compass 4 (4): 267-281.

Smith, T. Alexander and Raymond Tatalovich. 2003. Cultures at War: Moral Conflicts in Western Democracies. Toronto: Broadview Press.

Stark, Rodney. 1999. "Micro Foundations of Religion: A Revised Theory.” Sociological Theory 17 (3): 264-289.

Stark, Rodney and Roger Finke. 2000. Acts of Faith: Explaining the Human Side of Religion. Berkeley: University of California Press.

Stark Rodney and Laurence R. Iannaccone. 1994. “A supply-side reinterpretation of the “secularization” of Europe.” Journal for the Scientific Studies of Religion 33(3):23052.

Statistics Lithuania. 2013. "Ethnicity, mother tongue and religion.” Official Statistics Portal. Accessed from: <http://osp.stat.gov.lt/en/web/guest/informaciniaipranesimai articleId $=223122>$.

Stoll, Heather. 2008. "Social Cleavages and the Number of Parties: How the Measures You Choose Affect the Answers You Get.” Comparative Political Studies 41 (11): 14391465.

Stoll, Heather. 2013. Changing Societies, Changing Party Systems. New York: Cambridge 
University Press.

Studlar, Donley T., Alessandro Cagossi, and Robert D. Duval. 2013. “Is morality policy different? Institutional explanations for postwar Western Europe.” Journal of European Public Policy 20 (3): 353-371.

Taagepera, Rein. 1997. “Effective Number of Parties for Incomplete Data.” Electoral Studies 16 (2): $145-151$.

Taagepera, Rein and Matthew Soberg Shugart. 1989. Seats and Votes: The Effects and Determinants of Electoral Systems. New Haven: Yale University Press.

Torcal, Mariano and Scott Mainwaring. 2003. “The Political Recrafting of Social Bases of Party Competition: Chile, 1973-95.” British Journal of Political Science 33 (1): 5584.

Trejo, Guillermo. 2009. "Religious Competition and Ethnic Mobilization in Latin America: Why the Catholic Church Promotes Indigenous Movements in Mexico.” American Political Science Review 103 (3): 323-342.

Tribe, Laurence H. 1992. Abortion: The Clash of Absolutes. London: W.W. Norton \& Company.

Vaccarino, Franco, Heather Kavan, and Philip Gendall. 2011. "Spirituality and Religion in the Lives of New Zealanders.” Journal of Religion \& Spirituality in Society 1 (2): 8596.

van de Ven, Andrew H. 1976. “On the Nature, Formation, and Maintenance of Relations among Organizations.” The Academy of Management Review 1 (4): 24-36.

Wagner, Melinda Bollar. 1997. “The Demise of Denominationalism in Christian Schools.” Journal for the Scientific Study of Religion 36 (1): 13-24

Wimmer, Andreas, Lars-Erik Cederman, and Brian Min. 2009. “Ethnic politics and armed conflict: a configurational analysis of a new global dataset.” American Sociological 
Review 74 (2): 316-337. 
Table 1: An Illustration of the Impact of Religious Diversity on Party System Fragmentation

\begin{tabular}{|c|c|c|c|}
\hline Variables & $\begin{array}{l}\text { New Zealand } \\
(1996-2011)\end{array}$ & $\begin{array}{c}\text { Country } \\
\text { Lithuania } \\
\text { (1992-2008) }\end{array}$ & $\begin{array}{l}\text { Netherlands } \\
\text { (1998-2010) }\end{array}$ \\
\hline $\begin{array}{l}\text { Effective Number of } \\
\text { Parties (average) }\end{array}$ & 3.6 & 7.0 & 5.8 \\
\hline $\begin{array}{l}\text { Effective Number of } \\
\text { Ethnic Groups }\end{array}$ & 1.6 & 1.5 & 1.1 \\
\hline $\begin{array}{l}\text { Effective Number of } \\
\text { Religious Groups }\end{array}$ & 4.4 & 1.8 & 3.2 \\
\hline Electoral System & $\begin{array}{l}\text { Mixed-member } \\
\text { proportional }\end{array}$ & $\begin{array}{l}\text { Mixed-member } \\
\text { proportional }\end{array}$ & $\begin{array}{l}\text { List proportional } \\
\text { representation }\end{array}$ \\
\hline $\begin{array}{l}\text { District } \\
\text { Magnitude }\end{array}$ & 1 & 1 & 150 \\
\hline $\begin{array}{l}\% \text { Elected in an Upper } \\
\text { Tier (average) }\end{array}$ & 43.3 & 49.6 & N/A \\
\hline
\end{tabular}

Data for the average effective number of parties are calculated from data included in Bormann and Golder (2013). Information regarding each country's electoral system and district magnitude is also taken from Bormann and Golder (2013). Data for the effective number of ethnic groups are taken from Fearon (2003), while data for the effective number of religious groups are taken from Fearon and Laitin (2003). 
Table 2: Descriptive Statistics

\begin{tabular}{lcc}
\hline Variables & $\begin{array}{c}\text { Mean } \\
\text { (Standard Deviation) }\end{array}$ & $\begin{array}{c}\text { Minimum } \\
\text { (Maximum) }\end{array}$ \\
\hline ENEP & 4.02 & 1.23 \\
Religious Diversity: & $(1.96)$ & $(17.37)$ \\
Fearon and Laitin (logged) & 0.52 & 0.00 \\
Religious Diversity: & $(0.43)$ & $(1.53)$ \\
Alesina et al. (logged) & 0.64 & 0.00 \\
Religious Diversity: & $(0.50)$ & $(1.74)$ \\
Pew (logged) & 0.62 & 0.00 \\
Ethnic Diversity: & $(0.36)$ & $(1.63)$ \\
Fearon (logged) & 0.51 & 0.00 \\
LogM & $(0.44)$ & $(2.65)$ \\
& 1.36 & 0.00 \\
Upper Tier & $(1.32)$ & $(6.11)$ \\
& 6.06 & 0.00 \\
Proximity & $(13.55)$ & $(87.08)$ \\
& 0.29 & 0.00 \\
ENPRES & $(0.41)$ & $(1.00)$ \\
& 1.27 & 0.00 \\
& $(1.65)$ & $(8.65)$ \\
\hline
\end{tabular}


Table 3: The Relationship between Religious Diversity and Party System Fragmentation (ENEP)

\begin{tabular}{|c|c|c|c|}
\hline \multirow[b]{2}{*}{ Independent Variables } & \multicolumn{3}{|c|}{ Model } \\
\hline & 1 & 2 & 3 \\
\hline $\begin{array}{l}\text { Religious Diversity } \\
\text { (Fearon and Laitin) }\end{array}$ & $\begin{array}{l}-1.11 * * * \\
(0.39)\end{array}$ & & \\
\hline $\begin{array}{l}\text { Religious Diversity } \\
\text { (Alesina et al.) }\end{array}$ & & $\begin{array}{l}-1.06^{* * *} \\
(0.25)\end{array}$ & \\
\hline $\begin{array}{l}\text { Religious Diversity } \\
\text { (Pew) }\end{array}$ & & & $\begin{array}{l}-1.55^{* * *} \\
(0.42)\end{array}$ \\
\hline Ethnic Diversity & $\begin{array}{l}0.84^{* *} \\
(0.31)\end{array}$ & $\begin{array}{l}0.77 * * \\
(0.30)\end{array}$ & $\begin{array}{l}0.69 * * \\
(0.30)\end{array}$ \\
\hline $\log M$ & $\begin{array}{l}-0.06 \\
(0.19)\end{array}$ & $\begin{array}{l}-0.20 \\
(0.23)\end{array}$ & $\begin{array}{l}-0.43^{*} \\
(0.24)\end{array}$ \\
\hline $\begin{array}{l}\text { Log } M \times \text { Religious } \\
\text { Diversity }\end{array}$ & $\begin{array}{l}0.49 * * * \\
(0.16)\end{array}$ & $\begin{array}{l}0.52 * * * \\
(0.18)\end{array}$ & $\begin{array}{l}0.88^{* * *} \\
(0.21)\end{array}$ \\
\hline $\begin{array}{l}\text { LogM } \times \text { Ethnic } \\
\text { Diversity }\end{array}$ & $\begin{array}{l}0.41 * \\
(0.22)\end{array}$ & $\begin{array}{l}0.46^{*} \\
(0.24)\end{array}$ & $\begin{array}{l}0.53^{* *} \\
(0.23)\end{array}$ \\
\hline Upper Tier & $\begin{array}{l}0.03^{* *} \\
(0.02)\end{array}$ & $\begin{array}{l}0.04^{* *} \\
(0.02)\end{array}$ & $\begin{array}{l}0.05^{* *} \\
(0.02)\end{array}$ \\
\hline $\begin{array}{l}\text { Upper Tier } \times \text { Religious } \\
\text { Diversity }\end{array}$ & $\begin{array}{l}-0.00 \\
(0.01)\end{array}$ & $\begin{array}{l}-0.00 \\
(0.01)\end{array}$ & $\begin{array}{l}-0.01 \\
(0.02)\end{array}$ \\
\hline $\begin{array}{l}\text { Upper Tier } \times \text { Ethnic } \\
\text { Diversity }\end{array}$ & $\begin{array}{l}-0.03 \\
(0.03)\end{array}$ & $\begin{array}{l}-0.04 \\
(0.03)\end{array}$ & $\begin{array}{l}-0.06^{*} \\
(0.03)\end{array}$ \\
\hline Proximity & $\begin{array}{l}-3.29 * * * \\
(0.48)\end{array}$ & $\begin{array}{l}-3.10^{* * *} \\
(0.51)\end{array}$ & $\begin{array}{l}-3.16^{* * *} \\
(0.46)\end{array}$ \\
\hline ENPRES & $\begin{array}{l}0.13 \\
(0.13)\end{array}$ & $\begin{array}{l}0.16 \\
(0.12)\end{array}$ & $\begin{array}{l}0.20 \\
(0.13)\end{array}$ \\
\hline Proximity $\times$ ENPRES & $\begin{array}{l}0.90 * * * \\
(0.21)\end{array}$ & $\begin{array}{l}0.84 * * * \\
(0.20)\end{array}$ & $\begin{array}{l}0.84^{* * *} \\
(0.19)\end{array}$ \\
\hline Constant & $\begin{array}{l}3.73 * * * \\
(0.39)\end{array}$ & $\begin{array}{l}3.93 * * * \\
(0.36)\end{array}$ & $\begin{array}{l}4.20^{* * *} \\
(0.48)\end{array}$ \\
\hline$R^{2}$ & 0.35 & 0.36 & 0.36 \\
\hline$n$ & 747 & 740 & 740 \\
\hline
\end{tabular}


Figure 1: The Predicted Relationships between Religious Diversity (using the Fearon and Laitin measure) and Party System Fragmentation at Different Levels of District Magnitude

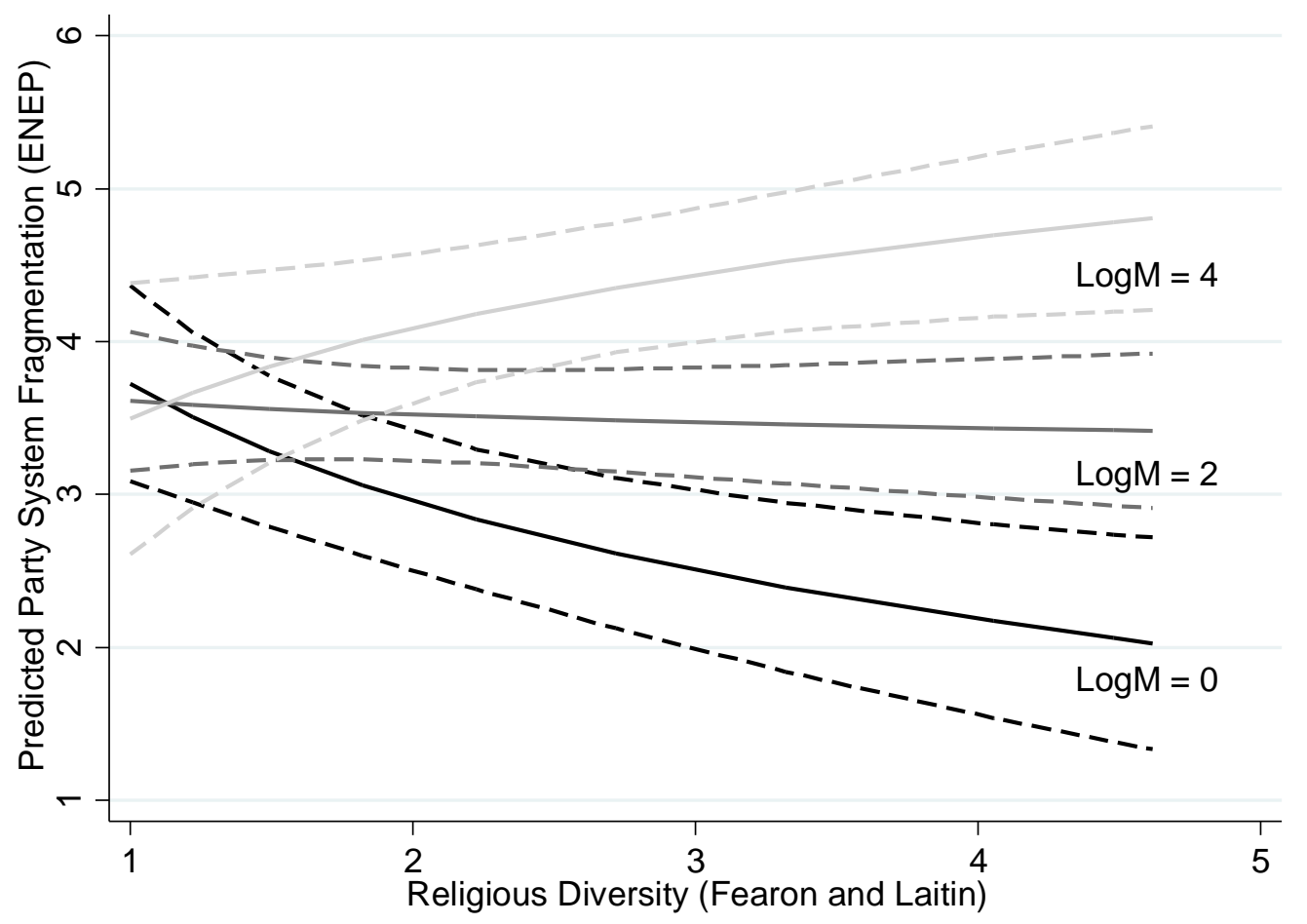

Notes: Black lines represent the relationship between religious diversity and party system fragmentation (ENEP) when $\log M=0$ (i.e. district magnitude is 1); gray lines represent the relationship between religious diversity and party system fragmentation when $\log M=2$ (corresponding to mean district magnitudes of $\sim 7.4$ ); while lines in light gray represent the relationship between religious diversity and party system fragmentation when $\log M=4$ (corresponding to mean district magnitudes of $\sim 54.6$ ). Dashed lines are $90 \%$ confidence intervals. The religious diversity scale is back-transformed in order to show the nonlinearity of the relationship. 
Figure 2: The Predicted Relationships between Religious Diversity (using the Alesina et al. measure) and Party System Fragmentation at Different Levels of District Magnitude

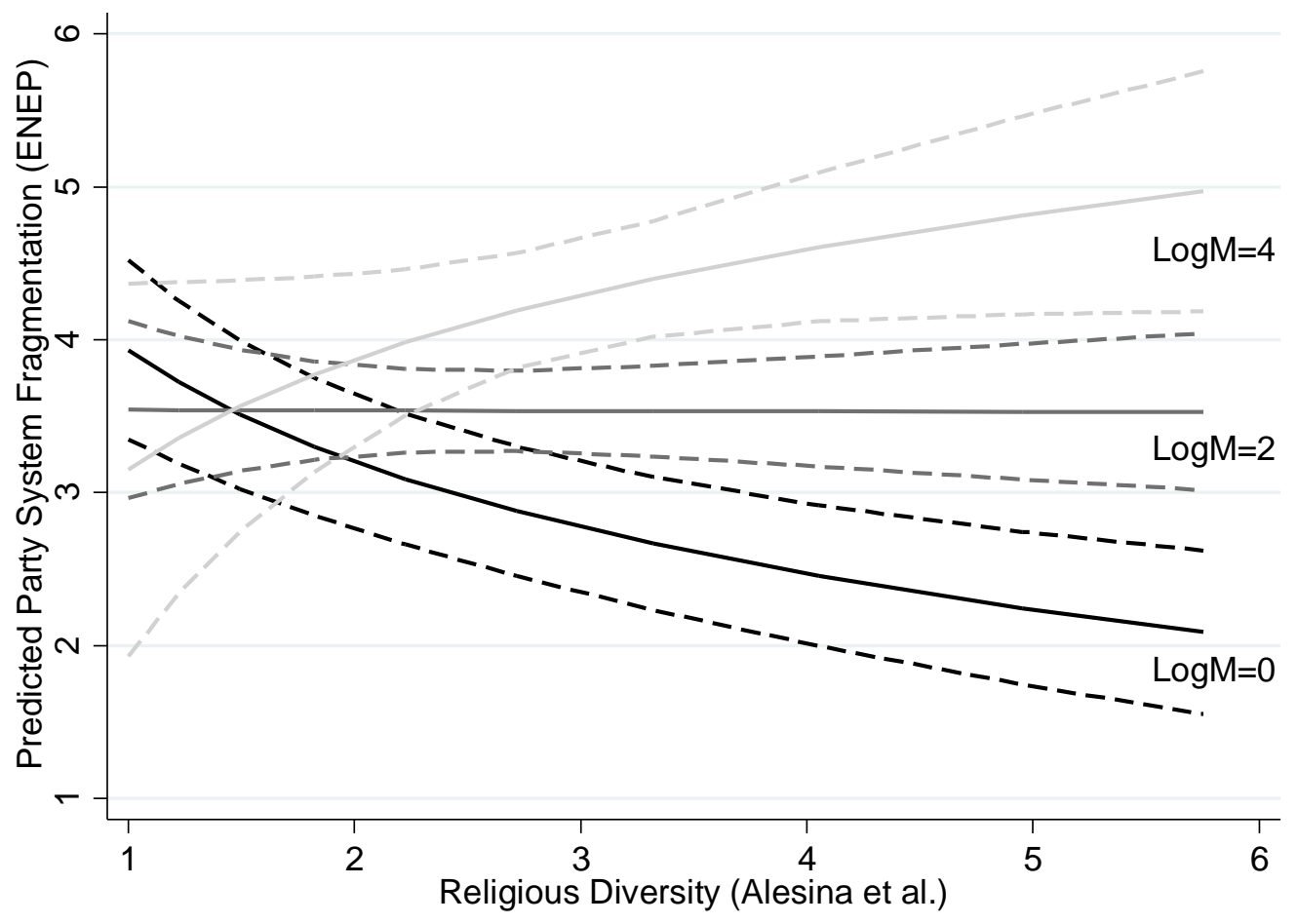

Notes: Black lines represent the relationship between religious diversity and party system fragmentation (ENEP) when $\log M=0$ (i.e. district magnitude is 1); gray lines represent the relationship between religious diversity and party system fragmentation when $\log M=2$ (corresponding to mean district magnitudes of $\sim 7.4$ ); while lines in light gray represent the relationship between religious diversity and party system fragmentation when $\log M=4$ (corresponding to mean district magnitudes of 54.6). Dashed lines are $90 \%$ confidence intervals. The religious diversity scale is back-transformed in order to show the nonlinearity of the relationship. 


\section{Figure 3: The Predicted Relationships between Religious Diversity (using the Pew measure) and Party System Fragmentation at Different Levels of District Magnitude}

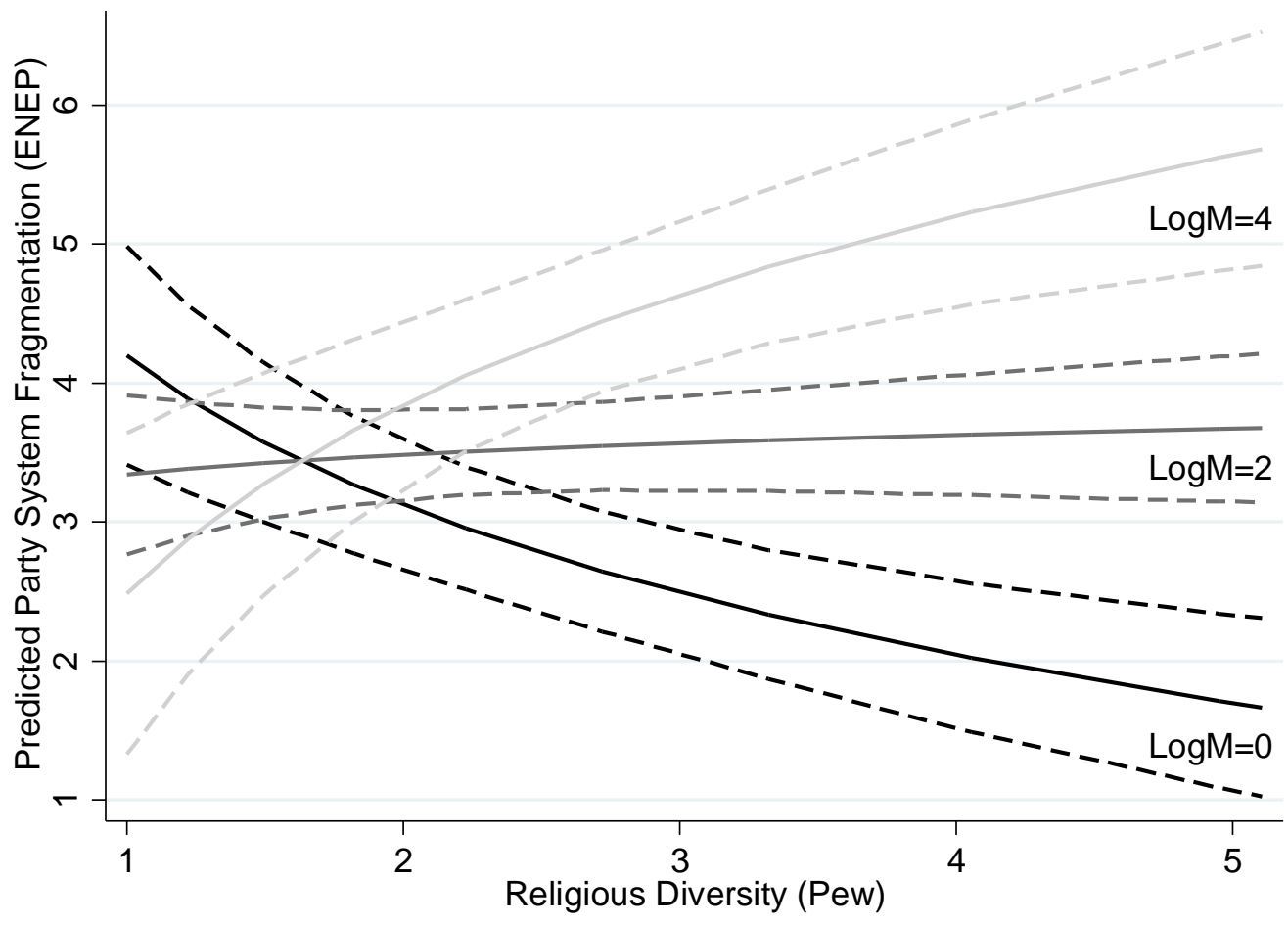

Notes: Black lines represent the relationship between religious diversity and party system fragmentation (ENEP) when $\log M=0$ (i.e. district magnitude is 1); gray lines represent the relationship between religious diversity and party system fragmentation when $\log M=2$ (corresponding to mean district magnitudes of $\sim 7.4$ ); while lines in light gray represent the relationship between religious diversity and party system fragmentation when $\log M=4$ (corresponding to mean district magnitudes of $\sim 54.6$ ). Dashed lines are $90 \%$ confidence intervals. The religious diversity scale is back-transformed in order to show the nonlinearity of the relationship. 
Appendix 1: Robustness Tests of the Relationship between Religious Diversity and Party System Fragmentation (ENEP)—Panel-Corrected Standard Errors

\begin{tabular}{|c|c|c|c|}
\hline \multirow[b]{2}{*}{ Independent Variables } & \multicolumn{3}{|c|}{ Model } \\
\hline & 4 & 5 & 6 \\
\hline $\begin{array}{l}\text { Religious Diversity } \\
\text { (Fearon and Laitin) }\end{array}$ & $\begin{array}{l}-1.11 * * * \\
(0.17)\end{array}$ & & \\
\hline $\begin{array}{l}\text { Religious Diversity } \\
\text { (Alesina et al.) }\end{array}$ & & $\begin{array}{l}-1.06^{* * *} \\
(0.13)\end{array}$ & \\
\hline $\begin{array}{l}\text { Religious Diversity } \\
\text { (Pew) }\end{array}$ & & & $\begin{array}{l}-1.55^{* * *} \\
(0.22)\end{array}$ \\
\hline Ethnic Diversity & $\begin{array}{l}0.84 * * * \\
(0.16)\end{array}$ & $\begin{array}{l}0.77 * * * \\
(0.16)\end{array}$ & $\begin{array}{l}0.69 * * * \\
(0.16)\end{array}$ \\
\hline $\log M$ & $\begin{array}{l}-0.06 \\
(0.11)\end{array}$ & $\begin{array}{l}-0.20 \\
(0.14)\end{array}$ & $\begin{array}{l}-0.43 * * * \\
(0.14)\end{array}$ \\
\hline $\begin{array}{l}\text { LogM } \times \text { Religious } \\
\text { Diversity }\end{array}$ & $\begin{array}{l}0.49 * * * \\
(0.09)\end{array}$ & $\begin{array}{l}0.52 * * * \\
(0.11)\end{array}$ & $\begin{array}{l}0.88 * * * \\
(0.13)\end{array}$ \\
\hline $\begin{array}{l}\log M \times \text { Ethnic } \\
\text { Diversity }\end{array}$ & $\begin{array}{l}0.41 * * * \\
(0.11)\end{array}$ & $\begin{array}{l}0.46 * * * \\
(0.13)\end{array}$ & $\begin{array}{l}0.53 * * * \\
(0.11)\end{array}$ \\
\hline Upper Tier & $\begin{array}{l}0.03 * * * \\
(0.01)\end{array}$ & $\begin{array}{l}0.04 * * * \\
(0.01)\end{array}$ & $\begin{array}{l}0.05 * * * \\
(0.01)\end{array}$ \\
\hline $\begin{array}{l}\text { Upper Tier } \times \text { Religious } \\
\text { Diversity }\end{array}$ & $\begin{array}{l}-0.00 \\
(0.01)\end{array}$ & $\begin{array}{l}-0.00 \\
(0.01)\end{array}$ & $\begin{array}{l}-0.01 \\
(0.01)\end{array}$ \\
\hline $\begin{array}{l}\text { Upper Tier } \times \text { Ethnic } \\
\text { Diversity }\end{array}$ & $\begin{array}{l}-0.03^{*} \\
(0.02)\end{array}$ & $\begin{array}{l}-0.04 * * * \\
(0.02)\end{array}$ & $\begin{array}{l}-0.06^{* * *} \\
(0.02)\end{array}$ \\
\hline Proximity & $\begin{array}{l}-3.29 * * * \\
(0.32)\end{array}$ & $\begin{array}{l}-3.10 * * * \\
(0.30)\end{array}$ & $\begin{array}{l}-3.16 * * * \\
(0.30)\end{array}$ \\
\hline ENPRES & $\begin{array}{l}0.13^{*} \\
(0.08)\end{array}$ & $\begin{array}{l}0.16^{* *} \\
(0.07)\end{array}$ & $\begin{array}{l}0.20 * * * \\
(0.08)\end{array}$ \\
\hline Proximity $\times$ ENPRES & $\begin{array}{l}0.90 * * * \\
(0.14)\end{array}$ & $\begin{array}{l}0.84 * * * \\
(0.13)\end{array}$ & $\begin{array}{l}0.84 * * * \\
(0.13)\end{array}$ \\
\hline Constant & $\begin{array}{l}3.73 * * * \\
(0.19)\end{array}$ & $\begin{array}{l}3.93 * * * \\
(0.19)\end{array}$ & $\begin{array}{l}4.20^{* * *} \\
(0.21)\end{array}$ \\
\hline$R^{2}$ & 0.35 & 0.36 & 0.36 \\
\hline$n$ & 747 & 740 & 740 \\
\hline
\end{tabular}


Appendix 2: Robustness Tests of the Relationship between Religious Diversity and Party System Fragmentation (ENEP)—Bootstrapped Standard Errors

\begin{tabular}{|c|c|c|c|}
\hline \multirow[b]{2}{*}{ Independent Variables } & \multicolumn{3}{|c|}{ Model } \\
\hline & 7 & 8 & 9 \\
\hline $\begin{array}{l}\text { Religious Diversity } \\
\text { (Fearon and Laitin) }\end{array}$ & $\begin{array}{l}-1.11^{* * *} \\
(0.18)\end{array}$ & & \\
\hline $\begin{array}{l}\text { Religious Diversity } \\
\text { (Alesina et al.) }\end{array}$ & & $\begin{array}{l}-1.06^{* * *} \\
(0.14)\end{array}$ & \\
\hline $\begin{array}{l}\text { Religious Diversity } \\
\text { (Pew) }\end{array}$ & & & $\begin{array}{l}-1.55^{* * *} \\
(0.25)\end{array}$ \\
\hline Ethnic Diversity & $\begin{array}{l}0.84 * * * \\
(0.19)\end{array}$ & $\begin{array}{l}0.77^{* *} \\
(0.19)\end{array}$ & $\begin{array}{l}0.69 * * * \\
(0.19)\end{array}$ \\
\hline $\log M$ & $\begin{array}{l}-0.06 \\
(0.13)\end{array}$ & $\begin{array}{l}-0.20 \\
(0.14)\end{array}$ & $\begin{array}{l}-0.43 * * * \\
(0.15)\end{array}$ \\
\hline $\begin{array}{l}\text { Log } M \times \text { Religious } \\
\text { Diversity }\end{array}$ & $\begin{array}{l}0.49 * * * \\
(0.11)\end{array}$ & $\begin{array}{l}0.52^{* * *} \\
(0.11)\end{array}$ & $\begin{array}{l}0.88^{* * *} \\
(0.13)\end{array}$ \\
\hline $\begin{array}{l}\text { LogM } \times \text { Ethnic } \\
\text { Diversity }\end{array}$ & $\begin{array}{l}0.41 * * * \\
(0.15)\end{array}$ & $\begin{array}{l}0.46 * * * \\
(0.15)\end{array}$ & $\begin{array}{l}0.53^{* * *} \\
(0.15)\end{array}$ \\
\hline Upper Tier & $\begin{array}{l}0.03^{* * *} \\
(0.01)\end{array}$ & $\begin{array}{l}0.04 * * * \\
(0.01)\end{array}$ & $\begin{array}{l}0.05^{* * *} \\
(0.02)\end{array}$ \\
\hline $\begin{array}{l}\text { Upper Tier } \times \text { Religious } \\
\text { Diversity }\end{array}$ & $\begin{array}{l}-0.00 \\
(0.01)\end{array}$ & $\begin{array}{l}-0.00 \\
(0.01)\end{array}$ & $\begin{array}{l}-0.01 \\
(0.01)\end{array}$ \\
\hline $\begin{array}{l}\text { Upper Tier } \times \text { Ethnic } \\
\text { Diversity }\end{array}$ & $\begin{array}{l}-0.03 \\
(0.02)\end{array}$ & $\begin{array}{l}-0.04^{* *} \\
(0.02)\end{array}$ & $\begin{array}{l}-0.06^{* * *} \\
(0.02)\end{array}$ \\
\hline Proximity & $\begin{array}{l}-3.29 * * * \\
(0.37)\end{array}$ & $\begin{array}{l}-3.10^{* * *} \\
(0.36)\end{array}$ & $\begin{array}{l}-3.16^{* * *} \\
(0.34)\end{array}$ \\
\hline ENPRES & $\begin{array}{c}0.13^{*} \\
(0.08)\end{array}$ & $\begin{array}{l}0.16 * * \\
(0.07)\end{array}$ & $\begin{array}{l}0.20^{* * *} \\
(0.08)\end{array}$ \\
\hline Proximity $\times$ ENPRES & $\begin{array}{l}0.90 * * * \\
(0.16)\end{array}$ & $\begin{array}{l}0.84 * * * \\
(0.15)\end{array}$ & $\begin{array}{l}0.84^{* * *} \\
(0.15)\end{array}$ \\
\hline Constant & $\begin{array}{l}3.73 * * * \\
(0.23)\end{array}$ & $\begin{array}{l}3.93 * * * \\
(0.21)\end{array}$ & $\begin{array}{l}4.20 * * * \\
(0.27)\end{array}$ \\
\hline$R^{2}$ & 0.35 & 0.36 & 0.36 \\
\hline$n$ & 747 & 740 & 740 \\
\hline
\end{tabular}


${ }^{1}$ Although New Zealand is home to a diverse number of ethnic groups, especially indigenous and other Pacific Islander groups, the number of people belonging to most groups is relatively small. This produces relatively low levels of ethnic diversity when measured using variables like the effective number of ethnic groups, which takes into account not only the number of groups but also the percentage of people belonging to each group.

${ }^{2}$ While it would be interesting to examine the impact of religious diversity on the total number of parties contesting each election, results for every party contesting the election are not available in many countries. Despite the absence of this information, ENEP remains an appropriate measure to test the argument outlined above because party system fragmentation reflects not only voters' actions (are votes fragmented among several parties or concentrated on fewer parties?) but the degree to which elites either cooperate (resulting in less party system fragmentation) or contest elections independently (resulting in greater party system fragmentation).

${ }^{3}$ Because the reporting of results by some electoral agencies combining the results of several smaller parties into one "other” category can create uncertain estimates as to the actual effective number of parties, I follow the practice of Clark and Golder (2006) and use Taagepera's (1997) correction to account for this uncertainty. However, the results presented here are substantively equivalent to those using the un-corrected measure of ENEP. ${ }^{4}$ Following the practice of Clark and Golder (2006), a number of countries were dropped from the analysis due to institutional peculiarities that potentially limited the ability to test a Duvergerian model. Namely, countries were dropped if they used a fused vote system (where voters cast one vote that counts for both the presidency and the legislature) or a majoritarian upper tier (which renders these countries incomparable to those using upper tiers to achieve greater proportionality). 
${ }^{5}$ Although the models presented here all use Fearon's (2003) measure of ethnic diversity, I substituted this measure with other measures of ethnic diversity—namely those produced by Alesina et al. (2003) and Wimmer, Cederman, and Min (2009)—and found results that confirm those presented here.

${ }^{6}$ While tensions between Sunni and Shi'a Muslims in some countries suggest that similar effort should be put into breaking down Muslim populations along Sunni and Shi'a lines, the Shi'a populations in the sample of countries used here were too small to have an impact of the construction of this variable.

${ }^{7}$ Multicollinearity among the independent variables was found to be quite low: variance inflation factor scores for all three religious diversity variables are below three (and variance inflation factor scores for all other variables are all below 10).

${ }^{8}$ I use $\log M$ values of two and four primarily for illustrative purposes. However, it is worth noting that $\log M$ values of two represent the median value of $\log M$ for all non-singlemember district systems in the sample. Note also that this and the other two measures of religious diversity are well-distributed from low to high at each level of $\log M$. 